\title{
Cupriavidus sp. HN-2, a Novel Quorum Quenching Bacterial Isolate, is a Potent Biocontrol Agent Against Xanthomonas campestris pv. campestris
}

\author{
Tian Ye ${ }^{1,2,+}$, Tian Zhou ${ }^{1,2,+}$, Qiting $\mathrm{Li}^{1,2,+}$, Xudan Xu ${ }^{1,2}$, Xinghui Fan ${ }^{1,2}$, Lianhui Zhang ${ }^{1,2}$ and \\ Shaohua Chen $1,2, *$ (i) \\ 1 State Key Laboratory for Conservation and Utilization of Subtropical Agro-bioresources, Guangdong \\ Laboratory of Lingnan Modern Agriculture, Integrative Microbiology Research Centre, South China \\ Agricultural University, Guangzhou 510642, China; 20182047012@stu.scau.edu.cn (T.Y.); \\ 20171021009@stu.scau.edu.cn (T.Z.); 201614090409@stu.scau.edu.cn (Q.L.); xuxudan@stu.scau.edu.cn (X.X.); \\ fxhscau@163.com (X.F.); lhzhang01@scau.edu.cn (L.Z.) \\ 2 Guangdong Province Key Laboratory of Microbial Signals and Disease Control, South China Agricultural \\ University, Guangzhou 510642, China \\ * Correspondence: shchen@scau.edu.cn; Tel.: +86-20-85288229 \\ + These authors contributed equally to this work.
}

Received: 11 December 2019; Accepted: 22 December 2019; Published: 25 December 2019

\begin{abstract}
Diffusible signal factor (DSF) represents a family of widely conserved quorum sensing (QS) signals involved in the regulation of virulence factor production in many Gram-negative bacterial pathogens. Quorum quenching, which disrupts QS either by degradation of QS signals or interference of signal generation or perception, is a promising strategy for prevention and control of QS-mediated bacterial infections. In this study, a novel DSF-degrading strain, HN-2, was isolated from contaminated soil and identified as Cupriavidus sp. The isolate exhibited superior DSF degradation activity and completely degraded $2 \mathrm{mmol} \cdot \mathrm{L}^{-1}$ of DSF within $24 \mathrm{~h}$. Analysis of the degradation products of DSF by gas chromatography-mass spectrometry led to the identification of trans-2-decenoic acid methyl ester as the main intermediate product, suggesting that DSF could be degraded by oxidation and hydroxylation. Moreover, this study presents for the first time, evidence that Cupriavidus sp. can reduce the black rot disease caused by Xanthomonas campestris pv. campestris (Xcc). Application of the HN-2 strain as a biocontrol agent could substantially reduce the disease severity. These findings reveal the biochemical basis of a highly efficient DSF-degrading bacterial isolate and present a useful agent for controlling infectious diseases caused by DSF-dependent bacterial pathogens.
\end{abstract}

Keywords: diffusible signal factor; Cupriavidus sp.; degradation activity; biocontrol; quorum sensing; Xanthomonas campestris pv. campestris

\section{Introduction}

Black rot pathogen Xanthomonas campestris pv. campestris $(X c c)$ has a wide host range but mainly infects cruciferous crops. Economically important cruciferous crops are consistently damaged by the black rot pathogen, and the death of plant tissues by Xcc infection leads to severe crop losses [1,2]. Black rot epidemiological studies revealed that black rot pathogen thrives in warm, humid climates and rapidly disseminates in the field to infect healthy crops [3]. The Xcc inoculum spreads from the infected seed to the epicotyl of healthy seeds, and as a result, cotyledons develop blackened margins and then shrivel and drop [1,4]. Bacteria propagate in young stems and leaves through the vascular system, and the disease appears as V-shaped chlorotic to necrotic lesions on leaf margins. During humid conditions, bacteria in guttation droplets are spread to neighboring plants by wind, rain, water splashes, and 
mechanical equipment [1,4]. Hydathodes, leaf wounds by insects, and roots are the main Xcc entry points in plants, but occasionally, infection also occurs through stomata [1]. Systemic Xcc infection in the host occurs from hydathodes of leaf margins into the plant vascular system and ultimately invasion of suture veins, which leads to the production of Xcc-infected seeds. Xcc can survive in soil plant debris for up to two years, although for not more than six weeks in free soil [1]. Long-distance Xcc transmission can also happen through flying insect vectors [5] (Figure 1).

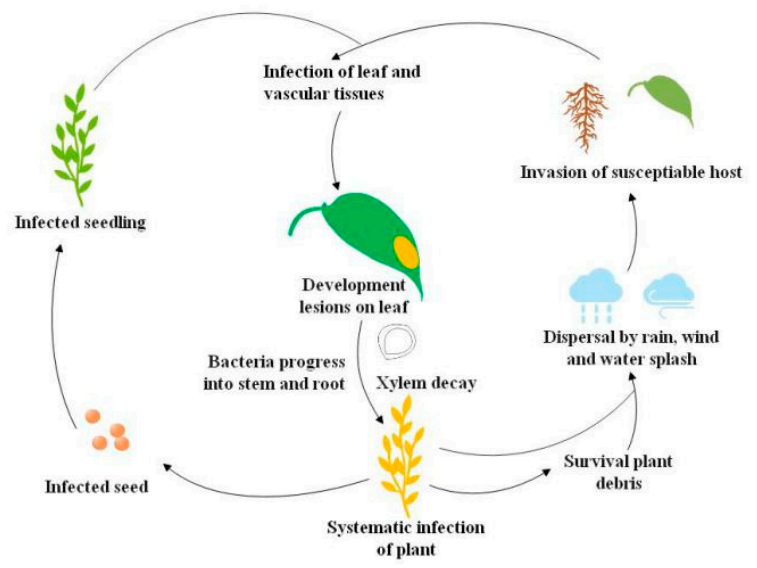

Figure 1. Life cycle of the black rot pathogen Xanthomonas campestris pv. campestris (Xcc) [5].

Diffusible signal factor (DSF) is structurally characterized as cis-11-methyl-2-dodecenoic acid (Figure 2) and is widely conserved in many Gram-negative bacterial pathogens such as Xcc, Xanthomonas oryzae pv. oryzae (Xoo), Stenotrophomonas maltophilia, Burkholderia cepacia, and Pseudomonas aeruginosa [6]. Accumulation of DSF activates the genes related to Xcc tissue-macerating pathogenicity [7]. Quorum sensing (QS) is the regulation of virulence factors at high population densities through cell-cell communication, and it inhibits premature activation of plant defense for successful infection [8,9]. QS can be simply understood as bacterial communication via the DSF [6,7]. QS regulates virulence factors including extracellular pectinolytic and cellulolytic enzymes, pectinases, lyases, xylanases, and cellulases, which contribute to the degradation of plant cell walls [10-13]. Disruption of QS may prevent the production of Xcc virulence factors, which makes it an appropriate target for the development of new phyto-protective agents [14].

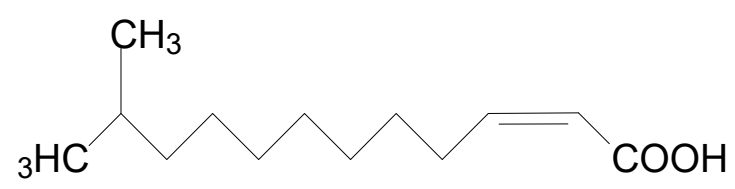

Figure 2. Chemical structure of diffusible signal factor (DSF).

Recently, exploration of bacteria for the biological control of plant pathogens has gained the keen interest of researchers. Inactivation of cell-to-cell signaling compounds, such as $N$-acyl homoserine lactone (AHL) and DSF, by bacterial degradation disrupts QS, a phenomenon known as quorum quenching (QQ) [15]. The first QQ bacteria were isolated from soil and identified as Gram-positive Bacillus sp. [16]. AHL-degrading bacteria have been reported to significantly decrease the virulence of the soft rot potato pathogens Pectobacteria atrosepticum and Pectobacteria carotovorum [15,17-19]. In contrast to other antimicrobial methods, this strategy efficiently attenuates the virulence without eradicating the pathogen $[20,21]$. However, studies on the QQ mechanism of DSF-degrading bacteria as an effective biocontrol approach are sparse in the literature. DSF degraders and their molecular mechanism and parameters for attenuating Xcc virulence have received little attention.

Herein, a novel DSF-degrading bacterial strain, Cupriavidus sp. HN-2, was identified as exhibiting superior DSF-degrading activity. Moreover, application of the strain HN-2 as a biocontrol agent could 
significantly reduce the black rot disease severity caused by Xcc. These results suggest that the HN-2 strain possesses promising potential that can be further expanded for better control of DSF-dependent pathogens and protection of plants from the respective infectious diseases.

\section{Materials and Methods}

\subsection{Chemicals and Plants}

DSF ( $\geq 99 \%$ ) was obtained from Shanghai UDChem Technology Co., Ltd (Shanghai, China). The chemical was dissolved in methanol at a stock concentration of $100 \mathrm{mmol} \cdot \mathrm{L}^{-1}$ and stored in dark bottles at $4{ }^{\circ} \mathrm{C}$ prior to use. Working solutions were made by diluting stock with culture medium and filtering it through a $0.2 \mu \mathrm{m}$ membrane. The pure active ingredient of the pesticide, streptomycin $(98 \%)$, was used as a positive control at $3.3 \mathrm{~g} \cdot \mathrm{mL}^{-1}$. Radishes (Raphanus sativus L.) were purchased from a local market (Guangzhou, China), and healthy plants were selected for the experiments.

\subsection{Bacterial Strains and Culture Conditions}

Black rot pathogen Xanthomonas campestris pv. campestris (Xcc), strain XC1, and Escherichia coli DH5 $\alpha$ were stocked in the laboratory. Xcc strains were maintained in Luria Bertani (LB) (composition $\left.\mathrm{g} \cdot \mathrm{L}^{-1}\right)$ : yeast extract 5.0, tryptone $\left.10.0, \mathrm{NaCl} 10.0\right)$ with Rifampicin $\left(30 \mu \mathrm{g} \cdot \mathrm{mL}^{-1}\right)$. Additionally, E. coli strains were grown in $\mathrm{LB}$ at $37^{\circ} \mathrm{C}$.

\subsection{Isolation of DSF-Degrading Bacteria from Soil Samples}

Soil samples were collected from the agricultural contaminated fields of the South China Agricultural University in July 2016. Approximately $300 \mathrm{~g}$ of soil were collected from the upper layer $(5-10 \mathrm{~cm})$, and samples were stored at $4{ }^{\circ} \mathrm{C}$ after collection. DSF-degrading bacteria were isolated using an enrichment procedure. To isolate DSF-degrading bacteria, $5 \mathrm{~g}$ soil samples were added to a minimal salt medium (MSM) (composition $\left(\mathrm{g} \cdot \mathrm{L}^{-1}\right)$ : $\left(\mathrm{NH}_{4}\right)_{2} \mathrm{SO}_{4} 2.0, \mathrm{Na}_{2} \mathrm{HPO}_{4} \cdot 12 \mathrm{H}_{2} \mathrm{O} 1.5, \mathrm{KH}_{2} \mathrm{PO}_{4}$ 1.5, $\left.\mathrm{MgSO}_{4} \cdot 7 \mathrm{H}_{2} \mathrm{O} 0.2, \mathrm{CaCl}_{2} \cdot 2 \mathrm{H}_{2} \mathrm{O} 0.01, \mathrm{FeSO}_{4} \cdot 7 \mathrm{H}_{2} \mathrm{O} 0.001, \mathrm{pH} 7.2\right)$ supplemented with DSF at a concentration of $1 \mathrm{mmol} \cdot \mathrm{L}^{-1}$ and cultivated for $7 \mathrm{~d}$ at $30{ }^{\circ} \mathrm{C}$ and $200 \mathrm{rpm}$. After $7 \mathrm{~d}$, the suspension was transferred to another MSM containing DSF $\left(2 \mathrm{mmol} \cdot \mathrm{L}^{-1}\right)$ at $10 \%$ inoculum and cultivated under the same conditions for $7 \mathrm{~d}$. The procedure was repeated until the DSF concentration increased to $4 \mathrm{mmol} \cdot \mathrm{L}^{-1}$. The final suspension was serially diluted $\left(10^{-1}\right.$ to $\left.10^{-8}\right)$ and spread on LB agar plates. After incubation at $30^{\circ} \mathrm{C}$ for $24-72 \mathrm{~h}$, colonies with different characteristics were selected and transferred to fresh medium. The procedure was repeated until a pure culture was obtained.

For the screening of the bacterial isolates, isolates were grown in MSM containing $2 \mathrm{mmol} \cdot \mathrm{L}^{-1} \mathrm{DSF}$ as the sole source of carbon for $24 \mathrm{~h}$ at $30^{\circ} \mathrm{C}$ and $200 \mathrm{rpm}$. After $24 \mathrm{~h}$, cultures were centrifuged, and the remaining DSF was extracted from the supernatant. The remaining amount of DSF was determined by high performance liquid chromatography (HPLC). The bacterial strain HN-2 was isolated from the soil samples and selected for further studies based on its effective DSF degradation.

\subsection{Identification of Strain $\mathrm{HN}-2$}

The morphology of strain HN-2 was studied by inoculating it on an LB medium for $24 \mathrm{~h}$ at $30{ }^{\circ} \mathrm{C}$. The colony and cellular morphologies of strain $\mathrm{HN}-2$ were investigated under an electron microscope (BH-2 Olympus, Tokyo, Japan) and a scanning electron microscope (XL-30 ESEM, Philips Optoelectronics Co., Ltd., Amsterdam, Holland) on LB plates and slides, respectively.

Bacterial strain HN-2 was also identified by partial sequence analysis of cloned $16 \mathrm{~S}$ rDNA genes. The strain was grown on LB, and PCR amplification of DNA was performed by using a $16 \mathrm{~S}$ rDNA universal bacterial primer set $27 \mathrm{~F}$ (5'-AGAGTTTGATCCTGGCTCAG-3') and $1492 \mathrm{R}$ (5'-GGTTACCTTGTTACGACTT-3'). PCR conditions were as follows: initial denaturation at $94{ }^{\circ} \mathrm{C}$ for $5 \mathrm{~min}, 32$ cycles of denaturation at $94{ }^{\circ} \mathrm{C}$ for $30 \mathrm{~s}$, annealing at $55^{\circ} \mathrm{C}$ for $30 \mathrm{~s}$, and an extension at $72{ }^{\circ} \mathrm{C}$ for $1 \mathrm{~min}$. The reaction followed a final extension at $72{ }^{\circ} \mathrm{C}$ for $5 \mathrm{~min}$. The PCR product was 
sequenced, and a homology search was carried out using BLAST (Basic Local Alignment Search Tool) (https://blast.ncbi.nlm.nih.gov/Blast.cgi) at the National Center for Biotechnology Information (NCBI) (https://www.ncbi.nlm.nih.gov) [22]. Sequences with close similarity were used for the identification and phylogenetic analysis of strain $\mathrm{HN}-2$.

\subsection{DSF Degradation Assays}

To study the relationship between DSF degradation and growth of isolate HN-2, DSF was added to cell suspensions of test strains, and the remaining DSF was detected with HPLC at different time intervals. Growth of HN-2 was calculated by using an ultraviolet spectrophotometer (GeneTech (Shanghai) Co., Ltd., Shanghai, China) at an optical density of $600 \mathrm{~nm}\left(\mathrm{OD}_{600}\right)$. The methodology was comprised of different steps as follows: $\mathrm{HN}-2$ isolate was inoculated into $5 \mathrm{~mL} \mathrm{LB}$ and incubated overnight at $30^{\circ} \mathrm{C}$ and $200 \mathrm{rpm}$. Overnight cultures were added to $50 \mathrm{~mL}$ MSM medium containing 2 $\mathrm{mmol} \cdot \mathrm{L}^{-1} \mathrm{DSF}$ and incubated at $30^{\circ} \mathrm{C}$ for $48 \mathrm{~h}$. Controls consisted of $50 \mathrm{~mL}$ MSM medium containing $2 \mathrm{mmol} \cdot \mathrm{L}^{-1}$ DSF. DSF was extracted three times from the supernatant with an equal volume of ethyl acetate. The mixture was dried in a rotary evaporator (Synthware, Beijing, China) and re-dissolved in $2 \mathrm{~mL}$ methanol. DSF was subsequently extracted and quantified at various incubation time intervals. Growth of HN-2 was also measured synchronously.

The extracted samples were subjected to HPLC with a $\mathrm{C}_{18}$ reverse-phase column and eluted with methanol and water $\left(80: 20, v / v\right.$, water containing $0.1 \%$ formic acid) at a flow rate of $1 \mathrm{~mL} \cdot \mathrm{min}^{-1}$. A diode array detector (Alliance e2695, Waters Corporation, Milford, MA, USA) was used for monitoring at the UV wavelength of $210 \mathrm{~nm}$.

\subsection{Identification of DSF Degradation Products}

To identify DSF and its degradation products, the HN-2 strain was grown in $100 \mathrm{~mL}$ MSM medium containing $2 \mathrm{mmol} \cdot \mathrm{L}^{-1}$ of DSF. Non-inoculated samples containing the same amount of DSF were used as controls. Samples of different times were treated at regular intervals as described above. Metabolites were detected by gas chromatography-mass spectrometry (GC-MS) (Model 7890B/5977B, Agilent Technologies Inc., Santa Clara, CA, USA). To identify the degradation products, mass spectrometry analyses were compared with the authentic standard compounds of the National Institute of Standards and Technology (NIST, Gaithersburg, MD, USA) library database.

The analytical conditions for GC-MS were as follows: injection amount, $1.0 \mu \mathrm{L}$; injection mode into the gas chromatograph, split with a 10:1 ratio; capillary column, HP-5 MS Ultra Inert column (30 $\backslash 0.25 \mu \mathrm{m} \backslash 0.25 \mu \mathrm{m}$, Agilent Technologies Inc., Santa Clara, CA, USA); column oven temperature, $60^{\circ} \mathrm{C}$ for $5 \mathrm{~min}$, then an increase of $10^{\circ} \mathrm{C} / \mathrm{min}$, followed by $300^{\circ} \mathrm{C}$ for $29 \mathrm{~min}$; injection port temperature, $280^{\circ} \mathrm{C}$; carrier gas, helium; analytical mode, scan mode. Mass spectra were recorded in the $\mathrm{m} / \mathrm{z}$ range of $40-430$.

\subsection{Biocontrol Assay of Strain HN-2 Against Xcc}

A biocontrol assay was carried out on slices of radish root (Raphanus sativus) [23]. Plants purchased from a local market were thoroughly washed under running tap water. Surface sterilization of plants was carried out by immersing plants sequentially in $44 \%$ sodium hypochlorite and $70 \%$ ethanol for 1 min followed by rinsing in sterile distilled water $(\mathrm{D} / \mathrm{W})$. The plant sterilization procedure was repeated three times, and slices of radish root $4-5 \mathrm{~mm}$ in thickness were prepared. Cupriavidus sp. $\mathrm{HN}-2$ $\left(9.6 \times 10^{7} \mathrm{CFU} \cdot \mathrm{mL}^{-1}\right)$ isolate was mixed with XC1 $\left(4 \times 10^{8} \mathrm{CFU} \cdot \mathrm{mL}^{-1}\right)$, and $100 \mu \mathrm{L}$ of the mixture was inoculated on each slice. Slices were placed in sterile plates and incubated at $28^{\circ} \mathrm{C}$ for $2 \mathrm{~d}$; the diameter of the macerated region was considered as the lesion diameter $(\mathrm{mm})$. Macerated tissue was scooped out and its weight was noted to compare with the initial weight of the tissue before inoculation, and maceration percentage was calculated. Five control groups included pure $\mathrm{HN}-2$, pure $\mathrm{XC1}, \mathrm{XC1}$ mixed with E. coli DH5 $\alpha\left(8 \times 10^{8} \mathrm{CFU} / \mathrm{mL}\right), \mathrm{XC1}$ mixed with agricultural streptomycin, and $\mathrm{D} / \mathrm{W}$, respectively. Three independent trials were carried out in triplicate. 


\subsection{Data Analysis}

Experiments were arranged as completely randomized designs with three replicates. Data were analyzed by one-way analysis of variance (ANOVA), and means were compared according to Bonferroni's multiple comparisons test using Graphpad Prism software (version 6). Statistical significance was determined by Tukey's honest significance difference (HSD) test at $p<0.05$ to examine specific differences between groups.

\subsection{GenBank Accession Numbers}

The 16S rDNA gene sequence of isolate Cupriavidus sp. HN-2 was submitted to GenBank (GenBank accession No. MG561941.1).

\section{Results}

\subsection{Isolation, Screening, and Identification of DSF-Degrading Isolates}

In this study, a simple and efficient method was developed to effectively screen DSF-degrading bacteria. According to the results of the soil enrichment culture, four morphologically different bacterial strains were attained by the streaking plate method and named as $\mathrm{HN}-1, \mathrm{HN}-2, \mathrm{HN}-3$, and $\mathrm{HN}-4$, respectively. The bacterial strains $\mathrm{HN}-1, \mathrm{HN}-2, \mathrm{HN}-3$, and $\mathrm{HN}-4$ degraded DSF $81.0 \%, 100 \%, 79.9 \%$, and $69.0 \%$ within $24 \mathrm{~h}$ of incubation, respectively (Table S1). The results showed that HN-2 possessed the highest degradation capacity among the four strains. Strain HN-2 completely degraded $2 \mathrm{mM}$ DSF within $24 \mathrm{~h}$ of incubation. In addition, the inhibition test indicated that strain $\mathrm{HN}-2$ showed no inhibitory activity against Xcc (Figure S1). Thus, strain HN-2 was selected for further studies.

Light and scanning electron microscopy revealed that strain $\mathrm{HN}-2$ is an aerobic, asporogenic, Gram-negative bacterium; it is ellipse to rod-shaped $(0.4-0.8 \times 0.6-1.2 \mu \mathrm{m})$, straight, and is without flagella (Figure S2). Strain colonies appear as circular, opaque, convex, and white on an LB plate. The cellular properties and colony morphology of strain HN-2 were similar to Cupriavidus pinatubonensis. According to BLAST results of the $16 \mathrm{~S}$ rDNA sequence on the NCBI, strain HN-2 showed high similarity ( $\geq 99 \%$ ) with different Cupriavidus strains (Table S2). Strain HN-2 was closely clustered with the Cupriavidus group in a phylogenetic tree and therefore was classified as a Cupriavidus sp. (Figure 3). Cupriavidus sp. strain HN-2 isolated in this study was deposited in the Guangdong Microbial Culture Center (CDMCC) under CDMCC 60432.

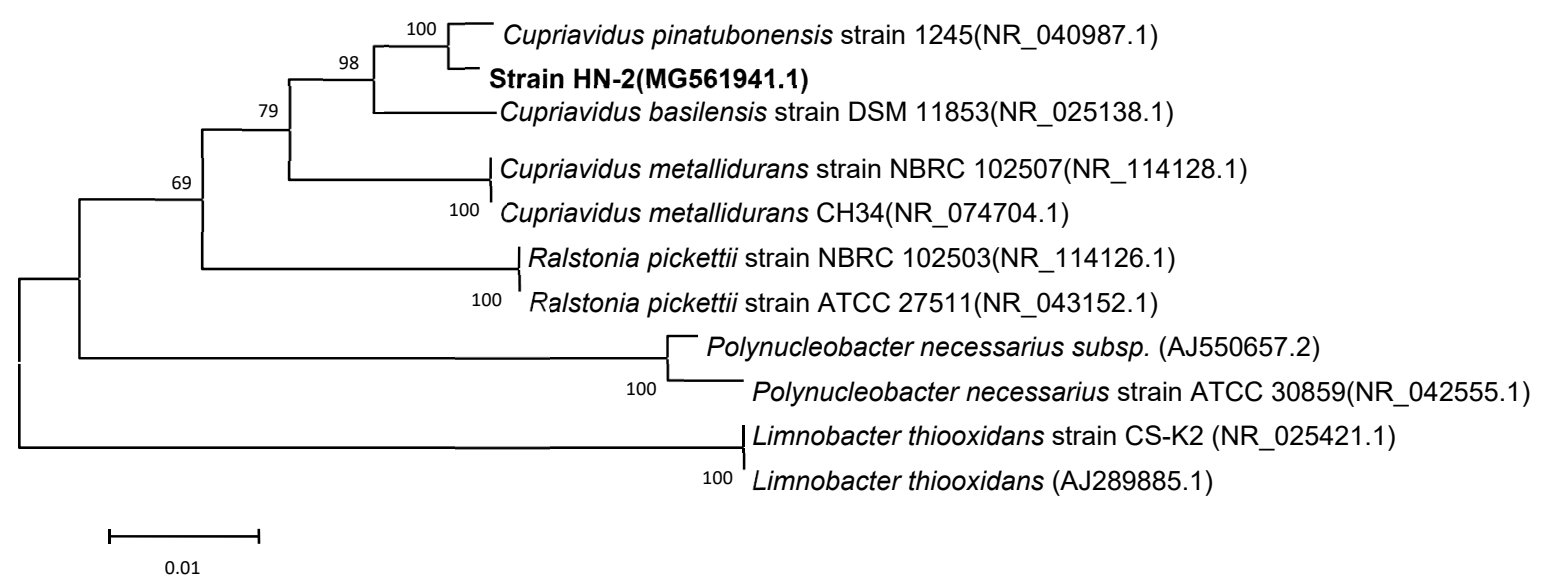

Figure 3. Phylogenetic tree based on the $16 \mathrm{~S}$ rDNA sequence of Cupriavidus sp. strain HN-2 (represented in bold) and related strains. Numbers in parentheses represent the sequence accession numbers in GenBank. Numbers at the nodes indicate the bootstrap values from neighborhood-joining analysis of 1000 re-sampled data sets. Bars represent sequence divergence. 


\subsection{DSF Degradation Kinetics}

To determine the quantitative differences between DSF degradation and HN-2 growth, DSF degradation was measured in vitro. Figure 4 presents the relationship between DSF degradation and growth of HN-2. DSF degradation was $42.1 \%, 100 \%, 100 \%$, and $100 \%$ after $12 \mathrm{~h}, 24 \mathrm{~h}, 36 \mathrm{~h}$, and $48 \mathrm{~h}$, respectively. During the fastest growing period $(0-12 \mathrm{~h})$, the $\mathrm{OD}_{600}$ reached 0.840 , and the DSF concentration decreased from 2.0 to $1.158 \mathrm{mmol} \cdot \mathrm{L}^{-1}$. DSF was completely degraded within $24 \mathrm{~h}$ (Figure 4, Figure S3). In contrast, degradation of the control group (without strain HN-2) was significantly lower and reached only $10 \%$ after $24 \mathrm{~h}$.

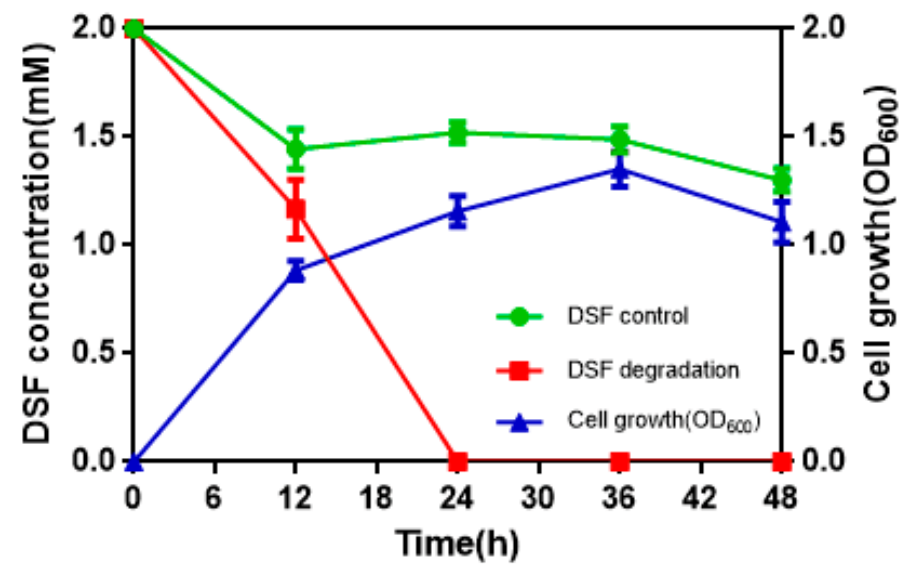

Figure 4. The relationship between diffusible signal factor (DSF) degradation and growth of strain HN-2. Values represent the mean of three trials. Each trial has three replicates. Bars indicate standard deviation of the mean.

\subsection{Degrading Products and Degradation Pathway of DSF}

Samples obtained at different times were analyzed through GC-MS to identify the degradation products during the bacterial degradation process. In the initial sample of the $0 \mathrm{~h}$ and $2.0 \mathrm{mM}$ DSF standard, a significant peak was detected at retention time (RT) of $16.972 \mathrm{~min}$, displaying a characteristic mass fragment $[\mathrm{M}+]$ at an $\mathrm{m} / \mathrm{z}$ value of 99.04 , with major fragment ions at $\mathrm{m} / \mathrm{z}$ values of 43.06 and 152.15 (Figure S4a), which were identified as DSF. Subsequently, the DSF disappeared concomitantly with the formation of a new compound with an $\mathrm{m} / \mathrm{z}$ value of 112.99 eluted at $16.977 \mathrm{~min}$. According to the similarity of the fragment retention times and molecular ions to those of the corresponding authentic compounds in the NIST library database, the compound was characterized as trans-2-decenoic acid methyl ester (Figure S4b). Finally, DSF was completely degraded by strain HN-2 without any persistent accumulative product.

A new degradation pathway of DSF in strain $\mathrm{HN}-2$ was proposed based on the chemical structures of DSF and the most probable degradation product formed during the metabolic process (Figure 5). First, the cis double bond of DSF was converted to a trans double bond by isomerase. Then, through $\beta$-oxidation of the fatty acid, trans-11-methyl-2-dodecenoic lost two carbons and $\beta$-oxidation stopped. The intermediate product lost a methyl group to produce a free methyl group and trans-2-decenoic acid. Then, the free methyl group replaced the hydrogen on the carboxyl group of trans-2-decenoic acid to form trans-2-decenoic acid methyl ester. 


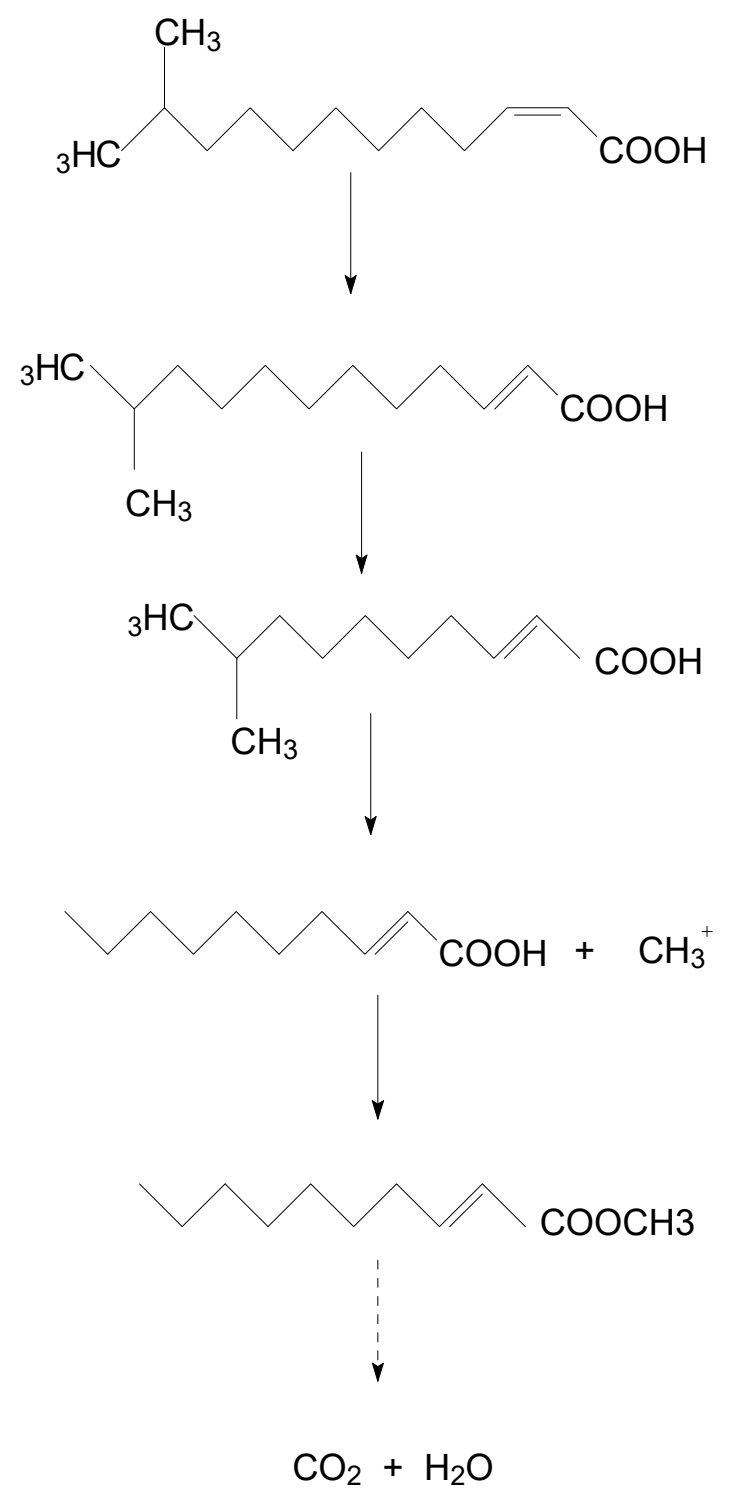

Figure 5. Proposed degradation pathway of DSF in strain HN-2.

\subsection{Biocontrol Potential of Isolate HN-2}

Strain HN-2 showed $100 \%$ biocontrol efficiency against Xcc on radish slices at a concentration of $9.6 \times 10^{7} \mathrm{CFU} \cdot \mathrm{mL}^{-1}$ (Figure 6). Plant slices treated solely with $\mathrm{XC} 1$ or an E. coli DH5 $\alpha$ and XC1 mixture resulted in severe incidence of disease (Figure 6A,D). Individual treatment of strain HN-2 significantly reduced disease severity caused by Xcc. Maceration was not observed in plant slices treated with a mixture of $\mathrm{HN}-2$ and $\mathrm{XC1}$ (Figures 6B and 7), similar to the treatment of agricultural streptomycin and the XC1 mixture (Figures 6C and 7). A biocontrol agent should not harm the host plant, and results of isolate HN-2 inoculation on surface-sterilized slices proved it safe for further use (Figure 6E). This study confirms the efficient DSF degrading bioactivity of isolate $\mathrm{HN}-2$ against the pathogen $\mathrm{XC} 1$ and presents it as a potential biological tool to control DSF-dependent bacterial pathogens. 


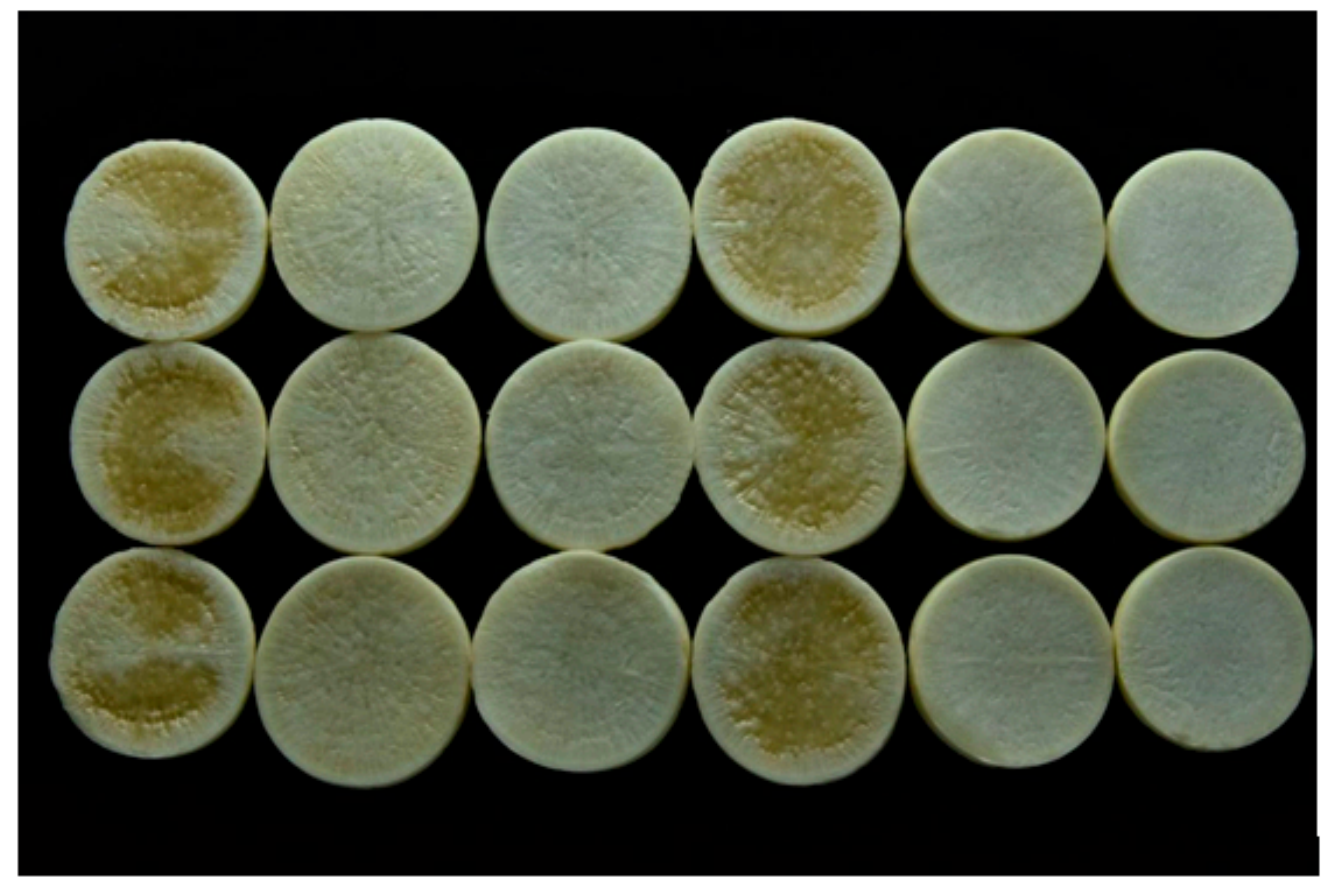
A
B
C
D
$\mathbf{E}$
F

Figure 6. Biocontrol test of strain $\mathrm{HN}-2$ against black rot disease on radish slices under laboratory conditions. (A) Xcc XC1 inoculated alone on radish. (B) Xcc XC1 + HN-2. (C) Xcc XC1 + agricultural streptomycin. (D) XccXC1 + E. coli DH5 $\alpha$. (E) HN-2 inoculated alone on radish. (F) Distilled water $(\mathrm{D} / \mathrm{W})$ inoculated on radish as control.
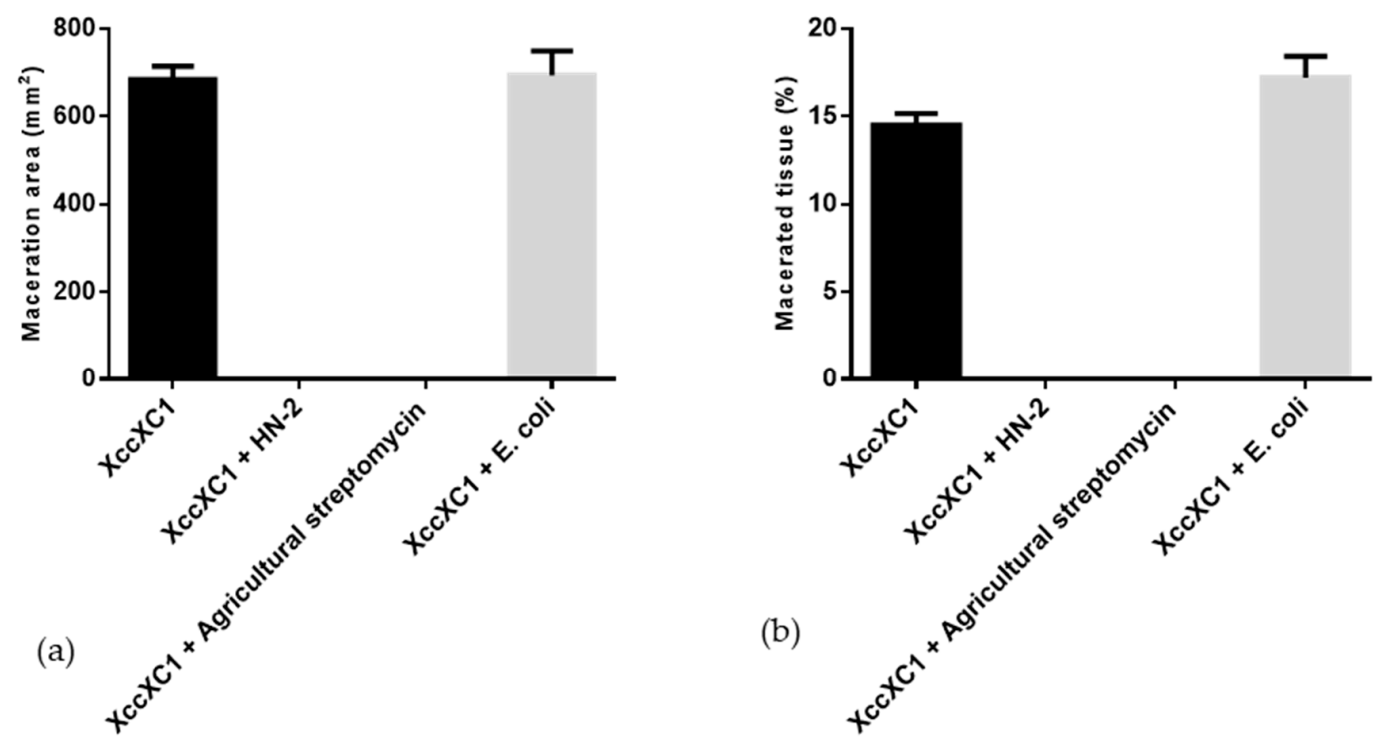

Figure 7. Quantification of radish tissue maceration. (a) Maceration area. (b) Macerated tissue. Values represent the mean of three trials. Each trial has three replicates. Bars indicate standard deviation of the mean. Statistical significance determined at $p<0.05$ according to the Tukey's honest significance difference (HSD) test.

\section{Discussion}

Bacteria employ different and efficient biological tools to manage bacterial and fungal plant diseases. However, only a few of them can rapidly degrade and inactivate the quorum sensing signal molecule DSF. In a search for naturally occurring biological control agents, a bacterial strain Cupriavidus 
sp. HN-2 from agricultural contaminated fields was screened for its biocontrol potential against Xcc. Moreover, few studies are available about the potential biocontrol activity of Cupriavidus sp. against Xcc. This study presents the first evidence that Cupriavidus sp. can substantially reduce the severity of black rot disease caused by Xcc.

QQ has recently been recognized as a potential new strategy for disease control [24-26]. Several Gram-negative pathogenic bacteria, including Agrobacterium, Brucella, Burkholderia, Enterobacter, Pectobacterium, Pseudomonas, Ralstonia, Serratia, Vibrio, and Yersinia, utilize QS to regulate their virulence, makes QS an emerging target for QQ biocontrol agents to control phyto-pathogens $[23,27,28]$. QQ strategies do not aim to kill pathogens but rather affect the expression of a specific function regulated by QS; therefore, they theoretically exert less selective pressure than biocide treatments. This makes QQ a valuable strategy to develop sustainable biocontrol agents and avoid antibiotic resistance [15,20,21,29-32]. In this regard, potential DSF degraders belonging to the genera Bacillus, Acinetobacter, Paenibacillus, Microbacterium, and Staphylococcus were isolated [27,28,33]. In the present study, a novel DSF-degrading isolate, HN-2, efficiently degraded the DSF signaling molecule of XC1 without affecting its growth. In addition, with the sequencing of the genome of the HN-2 strain, finding the gene clusters and enzymes responsible for DSF degradation may reveal the metabolic pathway for complete degradation and metabolism of DSF. We hypothesized that the cis double bond of DSF would be converted to a trans double bond by an isomerase. Then, through $\beta$-oxidation of the fatty acid, trans-11-methyl-2-dodecenoic lost two carbons, and $\beta$-oxidation did not continue. Catalyzed by an enzyme, the intermediate product lost a methyl group to produce a free methyl group and trans-2-decenoic acid. Then, the free methyl group replaced the hydrogen on the carboxyl group of trans-2-decenoic acid to form trans-2-decenoic acid methyl ester. Oxidation and hydroxylation play significant roles in the biodegradation of DSF.

In addition to its DSF-degrading capability, the biocontrol effects of the HN-2 isolate were also evaluated. Application of strain HN-2 as a biocontrol agent could substantially reduce the disease severity of Xcc. Antibiotic-producing Pseudomonas fluorescens could protect crops from root pathogens but its negative impact on the development of tomato roots limits its utility in the biological control of pathogens [34]. Interestingly, isolate HN-2 tested during the current study did not adversely affect the host plants. Potential biocontrol species must not be harmful to the host plants; therefore, any signal-molecule-degrading bacterial species cannot be used as a biological control agent. Similar to other pathogens, XC1 also has a broad host range and can infect plants of different families, including Brassicaceae (radish). During the bioassays, isolate $\mathrm{HN}-2$ not only survived on radish but also attenuated black rot symptoms. These characteristics reveal the potential of isolate HN-2 as a broad-range biocontrol agent and especially prove its utility in controlling the infectious diseases caused by DSF-dependent bacterial pathogens.

\section{Conclusions}

In this study, a novel quorum quenching bacterial isolate, Cupriavidus sp. HN-2, exhibiting potent biocontrol potential against Xcc, was identified. Strain HN-2 has superb DSF degradation activity and harbors the metabolic pathway for complete degradation and metabolism of DSF. Moreover, the application of strain HN-2 as a biocontrol agent could substantially reduce the disease severity of Xcc. These findings reveal the biochemical basis of a highly efficient DSF-degrading bacterial isolate and identify useful agents that exhibit the potential for biocontrol of infectious diseases caused by DSF-dependent bacterial pathogens. However, to develop an effective biological control agent, the bacterial strain should be comprehensively studied and optimized before field applications. An in-depth study of the gene clusters and enzymes responsible for DSF degradation by the sequencing of the genome of HN-2 strain will provide insights into the degradation mechanisms.

Supplementary Materials: The following are available online at http://www.mdpi.com/2076-2607/8/1/45/s1. 
Author Contributions: Conceptualization: L.Z. and S.C.; methodology: T.Y. and S.C.; data analysis: T.Y., T.Z., and Q.L.; writing—original draft preparation: T.Y.; writing—review and editing: T.Y., T.Z., Q.L., X.X., X.F., and S.C.; supervision, funding acquisition, and project administration: L.Z. and S.C. All authors have read and agreed to the published version of the manuscript.

Funding: This research was partly funded by the National Key Project for Basic Research of China (2015CB150600), the National Natural Science Foundation of China (31401763), Key Realm R\&D Program of Guangdong Province (2018B020206001), Guangdong Special Branch Plan for Young Talent with Scientific and Technological Innovation (2017TQ04N026), Guangdong Natural Science Funds for Distinguished Young Scholar (2015A030306038), and Climbing Project of Guangdong Province (pdjha0073).

Conflicts of Interest: The authors declare no conflicts of interest. The funders had no role in the design of the study; in the collection, analyses, or interpretation of data; in the writing of the manuscript, or in the decision to publish the results.

\section{References}

1. Alvarez, A.M. Black Rot of Crucifers. In Mechanisms of Resistance to Plant Diseases; Slusarenko, A.J., Fraser, R.S.S., van Loon, L.C., Eds.; Springer: Dordrecht, The Netherlands, 2000.

2. Williams, P.H. Black rot: A continuing threat to world crucifers. Plant Dis. 1980, 64, 736-742. [CrossRef]

3. Massomo, S.; Mabagala, R.; Swai, I.; Hockenhull, J.; Mortensen, C. Evaluation of varietal resistance in cabbage against the black rot pathogen, Xanthomonas campestris pv. campestris in Tanzania. Crop Prot. 2004, 23, 315-325. [CrossRef]

4. Derie, M.L. Black rot of crucifers in a cabbage seed field in western Washington. Plant Dis. 1988, $72,453$. [CrossRef]

5. An, S.Q.; Potnis, N.; Dow, M.; Vorholter, F.J.; He, Y.Q.; Becker, A.; Teper, D.; Li, Y.; Wang, N.; Bleris, L.; et al. Mechanistic insights into host adaptation, virulence and epidemiology of the phytopathogen Xanthomonas. FEMS Microbiol. Rev. 2019, 24. [CrossRef] [PubMed]

6. Wang, L.H.; He, Y.; Gao, Y.; Wu, J.E.; Dong, Y.H.; He, C.; Wang, S.X.; Weng, L.X.; Xu, J.L.; Tay, L.; et al. A bacterial cell-cell communication signal with cross-kingdom structural analogues. F1000—Post-Publ. Peer Rev. Biomed. Lit. 2004, 51, 903-912. [CrossRef]

7. Newman, K.L.; Chatterjee, S.; Ho, K.A.; Lindow, S.E. Virulence of plant pathogenic bacteria attenuated by degradation of fatty acid cell-to-cell signaling factors. Mol. Plant-Microbe Interact. 2008, 21, 326-334. [CrossRef]

8. Liu, H.; Coulthurst, S.J.; Pritchard, L.; Hedley, P.E.; Ravensdale, M.; Humphris, S.; Burr, T.; Takle, G.; Brurberg, M.-B.; Birch, P.R.J.; et al. Quorum sensing coordinates brute force and stealth modes of infection in the plant pathogen Pectobacterium atrosepticum. PLOS Pathog. 2008, 4, e1000093. [CrossRef]

9. Zhang, L.H.; Dong, Y.H. Quorum sensing and signal interference: diverse implications. Mol. Microbiol. 2004, 53, 1563-1571. [CrossRef]

10. Van Sluys, M.A.; Monteiro-Vitorello, C.B.; Camargo, L.E.; Menck, C.F.; Da Silva, A.C.; Ferro, J.A.; Oliveira, M.C.; Setubal, J.C.; Kitajima, J.P.; Simpson, A.J. Comparative genomic analysis of plant-associated bacteria. Annu. Rev. Phytopathol. 2002, 40, 169. [CrossRef]

11. Twomey, K.B.; O'Connell, O.J.; McCarthy, Y.; Dow, J.M.; O’Toole, G.A.; Plant, B.J.; Ryan, R.P. Bacterial cis-2-unsaturated fatty acids found in the cystic fibrosis airway modulate virulence and persistence of Pseudomonas aeruginosa. ISME J. 2012, 6, 939-950. [CrossRef]

12. Davies, D.G.; Marques, C.N.H. A fatty acid messenger is responsible for inducing dispersion in microbial biofilms. J. Bacteriol. 2009, 191, 1393-1403. [CrossRef] [PubMed]

13. Deng, Y.; Lim, A.; Lee, J.; Chen, S.; An, S.; Dong, Y.H.; Zhang, L.-H. Diffusible signal factor (DSF) quorum sensing signal and structurally related molecules enhance the antimicrobial efficacy of antibiotics against some bacterial pathogens. BMC Microbiol. 2014, 14, 51. [CrossRef] [PubMed]

14. Barnard, A.M.L.; Salmond, G.P.C. Quorum sensing in Erwinia species. Anal. Bioanal. Chem. 2007, 387, 415-423. [CrossRef] [PubMed]

15. Uroz, S.; Dessaux, Y.; Oger, P. Quorum sensing and quorum quenching: The Yin and Yang of bacterial communication. ChemBioChem 2009, 10, 205-216. [CrossRef] 
16. Dong, Y.H.; Xu, J.L.; Li, X.Z.; Zhang, L.H. AiiA, an enzyme that inactivates the acylhomoserine lactone quorum-sensing signal and attenuates the virulence of Erwinia carotovora. Proc. Natl. Acad. Sci. USA 2000, 97, 3526-3531. [CrossRef]

17. Constantinescu, F.; Reimmann, C.; Molina, L.; Michel, L.; Duffy, B.; Défago, G. Degradation of pathogen quorum-sensing molecules by soil bacteria: a preventive and curative biological control mechanism. FEMS Microbiol. Ecol. 2003, 45, 71-81.

18. Uroz, S. Novel bacteria degrading $\mathrm{N}$-acylhomoserine lactones and their use as quenchers of quorum-sensing-regulated functions of plant-pathogenic bacteria. Microbiology 2003, 149, 1981-1989. [CrossRef]

19. Smadja, B.; Latour, X.; Faure, D.; Chevalier, S.; Dessaux, Y.; Orange, N. Involvement of N-acylhomoserine lactones throughout plant infection by Erwinia carotovora subsp. atroseptica (Pectobacterium atrosepticum). Mol. Plant Microbe Interact. 2004, 17, 1269-1278. [CrossRef]

20. Faure, D.; Dessaux, Y. Quorum sensing as a target for developing control strategies for the plant pathogen Pectobacterium. Eur. J. Plant Pathol. 2007, 119, 353-365. [CrossRef]

21. Dessaux, Y.; Chapelle, E.; Faure, D. Quorum sensing and quorum quenching in soil ecosystems. Biocommun. Soil Microorg. 2011, 23, 339-367.

22. Altschul, S. Gapped BLAST and PSI-BLAST: a new generation of protein database search programs. Nucleic Acids Res. 1997, 25, 3389-3402. [CrossRef] [PubMed]

23. Garge, S.S.; Nerurkar, A.S. Evaluation of quorum quenching Bacillus spp. for their biocontrol traits against Pectobacterium carotovorum subsp. carotovorum causing soft rot. Biocatal. Agric. Biotechnol. 2017, 9, 48-57. [CrossRef]

24. Cui, X.; Harling, R. N-acyl-homoserine lactone-mediated quorum sensing blockage, a novel strategy for attenuating pathogenicity of Gram-negative bacterial plant pathogens. Eur. J. Plant Pathol. 2005, 111, 327-339. [CrossRef]

25. González, J.E.; Keshavan, N.D. Messing with bacterial quorum sensing. Microbiol. Mol. Boil. Rev. 2006, 70, 859-875. [CrossRef]

26. Zhang, L.H. Quorum quenching and proactive host defense. Trends Plant Sci. 2003, 8, 238-244. [CrossRef]

27. Ryan, R.P.; Fouhy, Y.; Garcia, B.F.; Watt, S.A.; Niehaus, K.; Yang, L.; Tolker-Nielsen, T.; Dow, J.M. Interspecies signalling via the Stenotrophomonas maltophilia diffusible signal factor influences biofilm formation and polymyxin tolerance in Pseudomonas aeruginosa. Mol. Microbiol. 2008, 68, 75-86. [CrossRef]

28. De Rossi, B.P.; Garcia, C.; Alcaraz, E.; Franco, M. Stenotrophomonas maltophilia interferes via the DSF-mediated quorum sensing system with Candida albicans filamentation and its planktonic and biofilm modes of growth. Rev. Argent. De Microbiol. 2014, 46, 288-297. [CrossRef]

29. Zhou, L.; Zhang, L.H.; Cámara, M.; He, Y.W. The DSF family of quorum sensing signals: Diversity, biosynthesis, and turnover. Trends Microbiol. 2017, 25, 293-303. [CrossRef]

30. Deng, Y.; Wu, J.; Eberl, L.; Zhang, L.H. Structural and functional characterization of diffusible signal factor family quorum-sensing signals produced by members of the Burkholderia cepacia complex. Appl. Environ. Microbiol. 2010, 76, 4675-4683. [CrossRef]

31. Deng, Y.; Wu, J.; Tao, F.; Zhang, L.H. Listening to a new language: DSF-based quorum sensing in Gram-negative bacteria. Chem. Rev. 2011,111,160-173. [CrossRef]

32. Zhang, J.W.; Xuan, C.G.; Lu, C.H.; Guo, S.; Yu, J.F.; Asif, M.; Jiang, W.J.; Zhou, Z.G.; Luo, Z.Q.; Zhang, L.Q. AidB, a novel thermostable $\mathrm{N}$-acylhomoserine lactonase from the bacterium Bosea sp. Appl. Environ. Microbiol. 2019, 85. [CrossRef] [PubMed]

33. Ye, T.; Zhou, T.; Fan, X.; Bhatt, P.; Zhang, L.; Chen, S. Acinetobacter lactucae strain QL-1, a novel quorum quenching candidate against bacterial pathogen Xanthomonas campestris pv. campestris. Front. Microbiol. 2019, 10, 2867. [CrossRef]

34. Brazelton, J.N.; Pfeufer, E.E.; Sweat, T.A.; Gardener, B.B.M.; Coenen, C. 2,4-Diacetylphloroglucinol alters plant root development. Mol. Plant Microbe Interact. 2008, 21, 1349-1358. [CrossRef] [PubMed]

(C) 2019 by the authors. Licensee MDPI, Basel, Switzerland. This article is an open access article distributed under the terms and conditions of the Creative Commons Attribution (CC BY) license (http://creativecommons.org/licenses/by/4.0/). 